\title{
A NEW PLAYER IN THE FIELD OF FINANCIAL AFFAIRS: THE FINANCIAL CONSUMER
}

\author{
Árpád Gyuris \\ E-mail: $\underline{\operatorname{arp} @ \text { index.hu }}$
}

\begin{abstract}
As a member of the EU, Hungary has to implement community norms into its legal order. The EU regulations have reached some basic institutions of the private and the business laws of the member states. The rules of consumer protection constitute the most important driving force behind the development. The current definition of the consumer intends to emphasize its weaker position in a contractual relationship. This definition seems to be in need of further specification in particular domains of transaction such as financial affairs.

Recent financial scandals in Hungary, such as the case of the foreign currency loans and the bankruptcy of broker-houses and banks call attention to the need of providing special protection to financial consumers as well. In this paper, I would like to examine, whether and to what extent the concept of the financial consumer is taken into consideration in the current Hungarian economic and legal literature, and what steps should be taken to restore the balace between financial service providers and consumers. I think that the introduction of the concept would help to disseminate knowledge about financial culture, and prevent further malpractice.
\end{abstract}

Keywords: consumer, financial culture, transactions

JEL classification: $\mathrm{G} 2, \mathrm{~K} 2$

\section{Introduction}

The idea of the consumer movement (consumerism) originated in the US in the 1960s and 1970s. In the United States Congress, J. F. Kennedy for example gave a speech about the four basic consumer rights (right to safety, right to be informed, right to choose, right to be heard) on March 15, 1962 (later called the Consumer Bill of Rights). In Europe the consumer protection became important in the 1980s. Certain issues of consumer protection, which involve the understanding of the specialities of consumer contracts, fall into the domain of contract law. Previously, the European Union has not interfered with the private legal norms of the member states, but the aim of protecting the consumer served a strong enough reason to introduce regulations in matters of consumer protection and contract law, following which several directives were introduced in the 1980s and 1990s. These include for example the 85/577/EEC directive on the protection of the consumer in respect of contracts negotiated away from business premises, the 87/102/EEC dirctive for the approximation of the laws, regulations, and administrative provisions of the Member States concerning consumer credit, the 90/314/EEC directive on package travel, package holidays, and package tours, and the 93/13/EEC directive on unfair terms in consumer contracts.

\section{The role of consumer}

The notion of the free market has often been imagined to be as the most ideal status of the economy (but the free market probably is not real).

At a perfect market, however, all parties, including the consumers, are assumed to have full information about the nature and value of the products. Since customers are clearly not in 
possession of such knowledge, the law tries to aid them by introducing special measures to reduce their information deficit. In the case of financial products, providing sufficient information about them might be problematic since the products are extremely complex and it is not clear what their essential properties are, and certain of their parameters can only be evaluated in the future (e.g. retirement pension) ${ }^{1}$.

The European Union worked out a definition of the concept consumer in the directives listed above, which was previously also unknown in Hungary but was adopted afterwards, due to the requirement of harmonization. According to this, a consumer is a natural person who buys a product or a service to satisfy his/her purposes which lie outside of his/her business or professional activity. The status of the consumer is an advantageous position. Some scholars think that the EU and the member states should apply the same general rules to other vulnerable groups of society, such as employees, or recipients of social security benefits ${ }^{2}$. It was already recognized in the 19th century that the weaker party needs to be protected. Protection materialized in compulsory norms, for example, those aiming to prevent house owners and employers to take advantage of tenants and employees, respectively. This kind of interference is paradoxical, however, since restrictions on freedom of contract are justified with freedom of contract as well: restrictions on the freedom of one party increase the freedom of the other one. ${ }^{3}$ Protection, however, has an impact on the prices of goods and services. Naturally, nobody wishes to question the good will behind the legal measures that aimed to help employees, tenants and consumers, but it is not always considered market friendly if the state interferes with private contractual affairs.

The Council Directive 85/577/EEC of 20 December 1985 to protect the consumer in respect of contracts negotiated away from business premises was among the first legal norms that aimed to define the concept of consumer. In this directive, consumer is viewed as , a natural person who, in transactions covered by this Directive, is acting for purposes which can be regarded as outside his trade or profession" (article 2).

The Council Directive 87/102/EEC of 22 December 1986 for the approximation of the laws, regulations and administrative provisions of the Member States concerning consumer credit defines the concept of consumer in an analogous manner. Ther consumer „means a natural person who, in transactions covered by this Directive, is acting for purposes which can be regarded as outside his trade or profession" (article 1).

The Council Directive 93/13/EEC of 5 April 1993 on unfair terms in consumer contracts, uses a minimally different version: consumer means any natural person who, in contracts covered by this Directive, is acting for purposes which are outside his trade, business or profession; (article 2 point $b$ )

The same definition of the concept of consumer is used in Directive 97/7/EC of the European Parliament and of the Council of 20 May 1997 on the protection of consumers in respect of distance contracts: 'consumer' means any natural person who, in contracts covered by this Directive, is acting for purposes which are outside his trade, business or profession; (article 2).

\footnotetext{
${ }^{1}$ Peter Cartwright (ed.): Consumer Protection in Financial Services Kluwer Law International London 1999 p. 15.

${ }^{2}$ Prugberger Tamás Észrevételek az új Ptk. egyes szerződéseket tartalmazó fejezetéhez a szolgálattal kapcsolatos szerződések hiánya miatt Jogtudományi közlöny, 2008. (63. évf.) 3. sz. p. 151-154.

${ }^{3}$ Konrad Zweigert, Hein Kötz: An Introduction to Comparative Law Oxford University Press 1998323 et seq
} 
The most current Directive 2011/83/EU of the European Parliament and of the Council of 25 October 2011 on consumer rights, amending Council Directive 93/13/EEC and Directive 1999/44/EC of the European Parliament and of the Council, and repealing replacing? Council Directive 85/577/EEC and Directive 97/7/EC of the European Parliament and of the Council Text with EEA relevance, stays with the well-known formulation: 'consumer' means any natural person who, in contracts covered by this Directive, is acting for purposes which are outside his trade, business, craft or profession (Article 2). In this definiton the new term craft was added by the EU, which extended the scope of the application.

It seems advantageous to divide the category of consumer into subcategories, of which the category of financial consumer is an interesting and important one. The study of this category even has special relevance in the face of the current scandals sorrounding banks and brokerage houses, in the efforts made in order to be able to better protect the disadvantaged consumer buying financial products. There seem to be two basic categories of financial consumers. The first one covers a natural person having money who would like to invest in financial products or open an account. In the case of these natural persons it seems useful to make a distinction between those who have larger sums of money at their disposal for this purpose and those who only have smaller sums. However, it is not clear where the dividing line between the two categories $\operatorname{lies}^{4}$.

The second category also covers natural persons, who, however, are exposed to the banks financially, because they would like to get money in the form of a loan. It primarily happens in the latter case that we find particularly disadvantageous situations for the consumer, since the bank can require the fulfillment of special requirements. If somebody wants to take a loan from a bank, the financial institution will make a decision after a very hard and long process, in the course of which they can monitor the whole private life of the consumer. The process is a guarantee for the bank but not for the consumer.

In every case, the key movement is the signing of the contract, which is neither automatic nor obligatory: the consumer can relatively freely decide on whether he/she can accept the conditions of the financial institution. There are two special issues related to the interaction between the financial consumer and the financial institution that we need to deal with. The first is that a financial institution is a special person, its establishment, operation and services have to be in accordance with the Hungarian legal order. Thus, a consumer can rely on the power of the Hungarian law. The second speciality is that the status of financial consumers is not always the same, they will fall into different categories depending on their status at the bank ('good'/'bad' creditors, VIP clients, etc.). If a financial consumer wishes to buy a financial product he/she is not going to be "a consumer" on the market, but a consumer of a particular kind for the bank. This procedure makes it possible for the bank to divide their consumers, but also helps the development of different packages of products or services.

\section{The foreign currency credit/loan contracts}

In the Hungarian Credit Act (2013./CCXXXVII.) the consumer is given the same definition as in the Consumer Act (1997/CLV) or in the Code Civil (2013/IV): a natural person who buys a

\footnotetext{
${ }^{4}$ Peter Cartwright (ed.): Consumer Protection in Financial Services Kluwer Law International London 1999 p. 11
} 
product or a service to satisfy his/her purposes which lie outside of his/her business or professional activities.

The Hungarian Credit Act defines the concept of financial institution, which can be a credit institution or a financial business. This is important because the law specifies that certain financial services can only be performed by financial institutions. According to the law $(\S 3)$, a financial business collects deposits or accepts cash or credit and provides a loan of money. A financial business provides one or more financial services.

A further important law concerns foreign currency loan. The Curia made a resolution (2/2014. PJE), and following this, the Hungarian parliament created a law. On the regulation of certain issues related to the resolution ('jogegységi') of the Curia on consumer credit contracts offered by financial businesses 2014/XXXVIII. The scope of the law extends to consumer credit contracts signed after 1 May 2004, (foreign currency-based, forint-based, or lease contracts where the general terms and conditions include foreign currency).

The main problem with the latter type of contracts was the application of different types of exchange rate. (For example, one rate when the contract had been signed, and another one when the repayment began). Under the new law, the official exchange rate of the National Bank of Hungary is the principal condition. In the case of foreign currency loans, banks were in the habit of amending contracts whenever and how they wanted, which is a strange thing to do in established contractual relationships. Additionally, building a system into a contract that automatically changes the conditions to the one that is favourable for the bank also raises several questions. It should be noted, however, that the disadvantaged consumers experienced with respect to these contracts would have been less if they had familiarized themselves properly with the details of the particular contracts. The law makes provisions for the case of unilateral contract modification. Paragraph 4 states that when a unilateral contract modification (on the part of the bank) is made possible (e.g. unilateral rate increase, cost increase, fee raise), the consumer loan agreement has to be considered as unfair (unless the above modifications were individually negotiated). The law also lists a few conditions when a contractual term of the bank has to be considered unfair: it is not clear and comprehensible to the consumer, the conditions of the unilateral contract modification are not fully defined, the unilateral amendment is not objective, there is a way for the bank to bring about a reason for the modification, the consumer could not have anticipated under what conditions an additional burden can be put on him/her, and the consumer is not given the right to terminate the contract in the case of contract amendment by the bank. (Note that in English law, it was discussed for certain clauses/terms excluding or restricting liability that they are necessarily unfair.)

According to the law, the financial business has to monitor the terms and conditions of its contractual practices, as to whether the conditions are unfair or not. A financial institution has to report to the Hungarian National Bank on the contracts containing terms of the above kind and declare whether it considers them fair or unfair. The above declaration has to include information on whether a one-sided raise of the interest or the costs has taken place. If the law predicts the unfairness of a term that is considered to be fair by the financial institution itself, the latter can initiate a civil process.

The procedure is interesting, because it forces the bank to have the terms investigated, which automatically has to be considered unfair if it bears certain formal features. The charge of unfairness can only be removed by the decision of the court. The question is whether this solution is to be considered fair and appropriate to a law state. The case appears fair since the court is involved, but the solution chosen by the Hungarian law maker appears to be equivalent 
to saying that the contract terms specified are unfair. It is obvious that the interference of the court has some advantages and there are certain motivations the Hungarian law maker had to take into consideration. This was the solution that seemed most appropriate for a law state, which enables the court to review the facts and consider special circumstances.

Above I discussed the method of dovetailing contracts and contractual responsibilities for a particular group of consumers. This applies particularly to those taking consumer credit, since in their case the credit sum and their abilities of repaying can be different.

\section{The special features of the the financial consumer}

Hesslon $^{5}$ emphasizes the double-sidedness of contract law: the special regulations help consumer contracts to be made freely, but with the content prescribed by law, which amounts to the restriction of the freedom of contract (which is connected with social issues and questions of economic efficiency). According to certain scholars, the compulsory rules of consumer protection restrict the freedom of contract, and thus hinder the development of private law. Atiyah (1995: 28) ${ }^{6}$ is of the opinion that the majority of people today are better prepared to make their own contracts and see their own interests without a paternalistic protection.

Ebers ${ }^{7}$ raises the question of how it can be decided whether someone is acting in a business or a personal matter. Does it matter how the contract was concluded? Can the buyer apply for protection as a consumer if he misled the seller in the course of the transaction and he used the goods as part of his business activity? As we have seen above, the directives that the European Union started to codify contract law with contain different definitions of the consumer.

The situation of the financial consumer raises issues of legislation and economics. If a financial institution wishes to stay in competition, it has to offer financial products that are attractive to as many consumers as possible, but has to pay attention to not asking for benefits for itself that its competitiors do not, since the consumers will then prefer the latters' products. It is not to be denied that the most important factor in a financial system is trust and predictability. It is a question to what extent special opportunities should be provided for the consumers, it is also to be expected that the person buying financial products is aware of the conditions, or is able to ask an expert. An undertaking always involves a particular amount of risk, the question is what the amount is, and to what extent one should be forced to take it. There are, however, certain mechanisms that try to enforce that, for example, the Hungarian National Bank is able to control financial services.

The common deposit base helps whenever financial service providers do not perform appropriately. There is also the possibility of the law maker interfering in the processes. But the neo-classical economic theory states that the consumers can only make decisions if they have enough information. Therefore the state intervention has not enough economic rationale due to invisible hand notion. The state has to ensure an appropriate legal nature ${ }^{8}$. In regulating financial services, the disclosure regulation is an important tool. For example, certain legal regulation can require that the current rate of the consumer credit should be specified.

\footnotetext{
5 Ton Hartlief Freedom and Protection in Contemporary Contract Law Journal of Consumer Policy September 2004, Volume 27, Issue 3, pp 253-267

${ }^{6}$,The great majority of people are today much better equipped to make their own contracts, and to judge their own interests without paternalistic protection." Patrick Atiyah: An Introduction to the Law of Contract (1995 5th Ed.) Clarendon Law Series, p. 28.

${ }^{7}$ Uniform Terminology for European Contract Law Ajani, Gianmaria - Ebers, Martin Nomos Verlagsges. MBH + Co, 2005 p.235.

${ }^{8}$ Sutatip Yuthayotin: Access to Justice in Transnational B2C Springer 2015 London
} 
It is worth considering some questions that are related to the role of the financial consumer. It is not to be denied that for a healthy economy, it is necessary to have a well-functioning system of financial institutions. It is also important to note that it is worth investing money in different financial products. The prudent functioning of financial institutions and the trust of consumers is indispensable for competitive economy. For this purpose, it is necessary to educate consumers on how it is possible to invest their savings. This efforts should start already at school $^{9}$. Besides the financial institutions there is a legal, half-legal and illegal market, which involves consumer fast loans, usury and loan contracts with firms or individuals. The market of the financial services is broad, and various products can be found: online insurence, online shopping, social fee, pensions, health insurance.

Another interesting point is the existence of financial consumer in special populations: students, high school pupils, older adults and people with low income. These people sometimes can be unbanked and underbanked, whom they need to give better access to small-dollar, short-term credit. In the US and other countries the vast varieties of business models are formed to give financial help ${ }^{10}$.

The most of the financial services are always available when somebody wishes to get some money or invest his money. Providing information is an important issue that cannot be emphasized enough. The average consumer, if he/she does not possess at least a minimum amount of information on financial institutions, and does not even read the information compulsorily provided with each product is very difficult to give appropriate information for, however. Most consumers are ill-equipped to come to decisions on their financial projects in the future. In the US many people do not see or understand even some basic financial concepts (calculating interest, accounting for inflation, understanding loan and mortgage terms). In addition to the lack of knowledge, financial consumers often do not show any interest in the terms of the contracts, only in the product or service, which explains why they willingly sign commitments, without thinking about the consequences, or about what issues can raise in the course of the fulfillment of the contract ${ }^{11}$. The financial institution will, of course, not decide or take responsibility instead of the consumers ${ }^{12}$.

The definition of the financial consumer, which is to a significant extent appropriate for the general case, has to be extended to a person that makes a contract with a financial institution (either as bank or broker firm). On the one hand, a settlement has to be made between the two parties, but if the consumer has taken the credit and has used the money as well, the settlement will be difficult to make. In this case, information brochures, credit counsellors, and information on the internet can be useful, because the consumer can prepare for potential conditions.

In my opinion, for consumer credit the state should a. make provisions that the banks should not change their conditions according to their own interests, b. monitor the options for taking

\footnotetext{
${ }^{9}$ Jonathan J. Fox, Suzanne Bartholomae: Financial Education and Program Evaluation pp. 47-68 In: Jing Jian Xiao: Handbook of Consumer Finance Research Springer New York 2008

${ }^{10}$ Nicolas P. Retsinas and Eric S. Belsky (eds.): Moving Forward The Future of Consumer Credit and Mortgage Finance Brookings Institution Press Washington 2011 p. 85

${ }^{11}$ An Offer You Cannot Negotiate: Some Thoughts on the Economics of Standard Form Consumer Contracts Aristides N. Hatzis* pp. 43-56 In: STANDARD CONTRACT TERMS IN EUROPE: A BASIS FOR AND A CHALLENGE TO EUROPEAN CONTRACT LAW, Hugh Collins, ed., Wolters Kluwer Law \& Business, Private Law in European Context Series, Vol. 15, pp. 43-56, 2008

${ }^{12}$ Andrea Ryan, Gunnar Trumbull, Peter Tufano: A Brief Postwar History of US Consumer Finance Working Paper 2010 Harvard Business School
} 
credit, prohibit and fine the use of certain conditions, and c. help certain groups of consumers in the process of taking credit (farmers, young people, socially disadvantaged groups).

Another interesting point related to the protection of the financial consumer is the access to justice, which helps the consumers to gain enough confidence to buy products in the market. There is an information deficit problem, if the traders ought to give relevant legal information to consumers (according to the precriptions of the legal norms). But there is a solution, for example there are many consumer organisations that can provide consumers with sufficient information ${ }^{13}$.

\section{Conclusions}

It is very important the financial systems should work in a predictable manner. The role and rights of the users of financial products, the financial consumers, is particularly interesting following the current scandals involving banks and brokerage firms. The European Union has initiated regulations concerning the general status of consumer. Regulations concerning a subcategory of the latter, that of the financial consumer, are currently under development, and need to be taken into consideration. Special intervention from the state seems necessary for the financial consumer because he/she is exposed to the financial service provider in several respects much more than an ordinary consumer who buys something on the internet, for example.

\section{References}

1. Ajani, Gianmaria and Ebers, Martin: Uniform Terminology for European Contract Law. Nomos Verlag, Baden-Baden. 2005.

2. Atiyah, Patrick: An Introduction to the Law of Contract. 5th edition. Clarendon Law Series, Oxford. 1995.

3. Botterill, Jacqueline: Consumer Culture and Personal Finance Money Goes to Market. Palgrave Macmillan, Basingstoke. 2010. http://dx.doi.org/10.1177/1469540511415468b

4. Cartwright, Peter (ed.): Consumer Protection in Financial Services. Kluwer Law International, London. 1999.

5. Fox, Jonathan J. and Suzanne Bartholomae: Financial Education and Program Evaluation. In: Handbook of Consumer Finance Research, Jing Jian Xiao, ed. Springer New York. pp. 47-68. 2008 http://dx.doi.org/10.1007/978-0-387-75734-6_ 4

6. Hartlief, Tom: Freedom and Protection in Contemporary Contract Law. Journal of $\begin{array}{llll}\text { Consumer } & \text { Policy 27/3: } & 253-267 .\end{array}$ http://dx.doi.org/10.1023/B:COPO.0000040519.54766.4a

7. Hatzis, Aristides N.: An Offer You Cannot Negotiate: Some Thoughts on the Economics of Standard Form Consumer Contracts. In: Standard Contract Terms in Europe: A Basis for and a challenge to European Contract Law, Hugh Collins, ed. Wolters Kluwer Law \& Business, Alphen aan den Rijn, pp. 43-56. 2008.

8. Prugberger, Tamás: Észrevételek az új Ptk. egyes szerződéseket tartalmazó fejezetéhez a szolgálattal kapcsolatos szerződések hiánya miatt. Jogtudományi közlöny 63/3: 151-154. 2008 .

9. Retsinas, Nicolas P. and Eric S. Belsky (eds.): Moving Forward. The Future of Consumer Credit and Mortgage Finance. Brookings Institution Press, Washington. 2011.

\footnotetext{
${ }^{13}$ Stefan Wrbka: European Consumer Access to Justice Revisited Cambridge University Press 2015 Cambridge 298-300
} 
10. Ryan, Andrea, Gunnar Trumbull, and Peter Tufano: A Brief Postwar History of US Consumer Finance. Working Paper, Harvard Business School. 2010. http://dx.doi.org/10.2139/ssrn.1723397

11. Stefan Wrbka: European Consumer Access to Justice Revisited. Cambridge University Press, Cambridge. 2015. http://dx.doi.org/10.1017/CBO9781139680431

12. Yuthayotin, Sutatip: Access to Justice in Transnational B2C. Springer, London. 2015. http://dx.doi.org/10.1007/978-3-319-11131-5

13. Zweigert, Konrad, and Hein Kötz: An Introduction to Comparative Law. Oxford University Press, Oxford. 1998. http://dx.doi.org/10.1017/S0020589300063892 